\title{
Fertility-sparing surgery in advanced stage malignant ovarian germ cell tumor: a case report
}

\author{
Montassar Ghalleb, Hatem Bouzaiene, Skander Slim, Achraf Hadiji, Monia Hechiche, Jamel Ben Hassouna
} and Khaled Rahal

\begin{abstract}
Background: Malignant ovarian germ cell tumor is a rare type of disease, which generally has a good prognosis due to the high chemosensitivity of this type of tumor.

Fertility preservation is an important issue because malignant ovarian germ cell tumor commonly affects young women. Although conservation is the standard for early stage, it becomes more debatable as the disease progresses to more advanced stages.

Aim: Report the case of a patient with an International Federation of Gynecology and Obstetrics Stage Illc malignant ovarian germ cell tumor, who had conservative surgery and chemotherapy with a good fertility outcome.

Case presentation: A 23-year-old North African woman with a left malignant ovarian germ cell tumor stage Illc was treated by left adnexectomy and omentectomy followed by chemotherapy. A 15-year follow-up showed no signs of relapse, and she completed three full-term natural pregnancies.

Conclusions: Malignant ovarian germ cell tumor is a rare ovarian tumor with a good prognosis. It is usually associated with a good fertility outcome in early stages. However, due to the rarity of the disease in advanced stages, the fertility outcome for this group of patients is not clear. This lack of data surrounding advanced stages points to the need for a meta-analysis of all published cases.
\end{abstract}

Keywords: Fertility, Surgery, Malignant germ line tumor

\section{Background}

Malignant ovarian germ cell tumor (MOGCT) is a rare disease. It represents 5 to $7 \%$ of all ovarian malignancies $[1,2]$. There is a variety of histologic types: dysgerminoma, immature teratoma, yolk sac tumor, choriocarcinoma, polyembryoma, and mixed MOGCT. They differ from epithelial ovarian cancer in two aspects: the younger age of the affected population and their good prognosis. The latter is explained by the higher number of diagnoses at early stages and their high chemosensitivity [3, 4].

Fertility-sparing surgery (FSS) is the cornerstone of treatment in early stage disease. In advanced stage MOGCT, conservative surgery for young patients who

\footnotetext{
* Correspondence: slim.skander@gmail.com

Surgical Oncology Department, Salah Azaiez Institute of Cancer, Tunis, Tunisia
}

(c) The Author(s). 2017 Open Access This article is distributed under the terms of the Creative Commons Attribution 4.0 International License (http://creativecommons.org/licenses/by/4.0/), which permits unrestricted use, distribution, and reproduction in any medium, provided you give appropriate credit to the original author(s) and the source, provide a link to the Creative Commons license, and indicate if changes were made. The Creative Commons Public Domain Dedication waiver (http://creativecommons.org/publicdomain/zero/1.0/) applies to the data made available in this article, unless otherwise stated. desire pregnancy can be justified after discussion with the patient [4].

Patients with MOGCTs have a relative good pregnancy rate even in advanced stages [5].

Our aim is to report a case of advanced MOGCT with a 15-year survival and an excellent fertility outcome of three spontaneous pregnancies.

\section{Case presentation}

A 23-year-old North African woman, with no past personal or familial medical history, requested a consultation for acute abdominal pain and deterioration of her general status.

After a physical examination, she was found to be afebrile with a whole abdominal tenderness but no signs of peritonitis. A vaginal examination found a mobile tender mass in the pouch of Douglas. The remaining part 
of the physical examination was normal. A pelvic ultrasound showed a $22 \times 15 \mathrm{~cm}$ simple left ovarian cyst. In view of her acute abdominal pain, she was scheduled for an emergency cystectomy. A $25 \mathrm{~cm}$ left ovarian tissular mass with external vegetation associated with a moderate ascites and peritoneal implants were observed; the rest of her abdominal cavity appeared normal.

A left adnexectomy was also conducted. The frozen section showed a malignant germ cell tumor. The surgery was completed by omentectomy and excision of all the peritoneal implants. A final histologic examination showed a mixed MOGCT associating a seminomatous component to a yolk sac tumor. The peritoneal implants were metastatic.

It was at that time that she was referred to our center.

She underwent chemotherapy consisting of bleomycin, etoposide, and cisplatin (BEP), with a complete clinical and radiological response after four courses of BEP. Finally, she underwent six well-tolerated injections of BEP with no chemo-induced amenorrhea.

She was then contacted for follow-ups for the next 16 years. They were initially conducted every 4 months, including physical examinations and tumor markers. Two years post-treatment, follow-ups were conducted every 6 months for the next 3 years. She then received annual follow-ups for the remainder of the time. An abdominopelvic sonography was also conducted annually. The tumor markers were negative during all follow-ups and there have been no signs of relapse to this date.

She also reported three full-term natural pregnancies, occurring respectively 4,6 , and 10 years after the end of the treatment.

\section{Discussion}

Through this case report we have observed that, despite the advanced stage, FSS can offer both oncologic safety and good reproductive outcome.

\section{Oncologic safety}

Because of the rarity of advanced stage MOGCTs, they comprise approximately 20 to $30 \%$ of all MOGCTs [6], few cases have been reported in the literature. As such, the safety of FSS for this disease is accepted but not yet fully clinically supported.

Alternatively, many studies $[4,7,8]$ targeting all stages of development (I to IV) have shown excellent survival outcomes of FSS. This was the case even for advanced stages, and the reproductive outcomes appeared extremely encouraging. Park et al. [4] showed that diseasefree survival (DFS) and overall survival (OS) were not compromised after FSS in advanced stage (stage II to IV) MOGCTs.

In the study of Low et al. [8], the overall mean followup duration was 52.1 months, and there were only one out of 18 fatalities $(\mathrm{OS}=94.4 \%)$. In Perrin et al. [7], the 5 -year OS rate was seven out of eight patients (88\%).

A study published in 2015 by Yang et al. [9] examined 104 patients with histologically confirmed MOGCT that were divided into two groups: a fertility-preserving group of 59 cases and a non-fertility-preserving group of 45 cases. This study showed that the mortality rate of the fertility-preserving group was $15.3 \%$ lower than that of the non-fertility-preserving group $(31.1 \% ; p=0.054)$. The tumor-free survival rate in the fertility-preserving surgery group was $79.7 \%$, which was higher than that of the non-fertility-preserving surgery group which was $57.8 \%(p=0.016)$. The 5-year progression-free survival (PFS) rates in the fertility-preserving surgery group and the non-fertility-sparing group were of 67.6 and $63.3 \%$, respectively.

Ertas et al. [10] showed that in 42 cases of patients with MOGCT treated by FSS the OS rates were $100 \%$ for patients with pure dysgerminoma, $81.4 \%$ for patients with non-dysgerminoma tumor, $97.4 \%$ for early stage disease, and 77\% for advanced stage disease, respectively.

Based on these results, FSS is widely accepted as a surgical approach for young women desiring pregnancy.

\section{Reproductive outcome}

In previous studies $[4,11-13]$, most patients had normal menstruation and their ovarian function was very promising after BEP chemotherapy.

Park et al. [4] reported that 15 out of 20 patients (75\%) with MOGCT, all stages combined, succeeded in their attempts to conceive: 21 pregnancies were reported with 13 live births. As such, reproductive outcomes are encouraging after FSS, even in patients who received adjuvant BEP chemotherapy.

In another study, Brewer et al. [5] showed that $71 \%$ of patients maintained their normal menstrual function during and after chemotherapy, including patients with advanced stage disease.

In their study, Yang et al. [9] found that in the fertility-preserving group of 39 patients that attempted to conceive, there was a total of 31 successful pregnancies. The pregnancy rate was $79.5 \%$, and the total number of pregnancies was 37.

In another study conducted by Ertas et al. [10], 58\% of those receiving chemotherapy were amenorrheic during treatment while $85 \%$ resumed regular menses after completing chemotherapy. The fertility rates were $77 \%$ for those who received adjuvant chemotherapy after FSS and $62.5 \%$ for those who did not receive it.

These studies point to the expectation that advanced stage MOGCT can be cured with maintenance of normal reproductive function when treated with conservative surgery and BEP chemotherapy. 


\section{Conclusions}

MOGCT is a rare disease, usually affecting young patients. Therefore, the preservation of fertility should be the aim for the gynecologic oncologist. This case, as with the few other cases reported in the literature, showed that conservative treatment in advanced stages can yield good results as it relates to oncologic safety and reproductive outcomes. As such, treatment can be presented as an option to patients after offering a clear explanation and obtaining full consent. On the other hand, and due to the rarity of research on advanced stages of the disease, the need for more case series and meta-analyses is crucial to obtain a higher grade of recommendation to FSS in advanced stage MOGCT.

\section{Acknowledgements}

We want to acknowledge the archive department of the Salah Azaiez Institute of Oncology in Tunis for their help.

We acknowledge Dr Noura Khayat and Dr Asma Mathlouthi for the language support.

\section{Funding}

Not applicable.

\section{Availability of data and materials}

Not applicable.

\section{Authors' contributions}

MG, SS: data collection, review of the literature, and drafted the manuscript $H B$, AH: review of the literature and drafted the manuscript. $M H, J B H, K R$ :

drafted the manuscript. All authors read and approved the final manuscript.

\section{Ethics approval and consent to participate}

We declare no conflicts of interest between the authors and that this work was made with all due respect to the code of ethics under the supervision of the medical and ethic committee of the Salah Azaiez Institute.

\section{Consent for publication}

Written informed consent was obtained from the patient for publication of this case report and any accompanying images. A copy of the written consent is available for review by the Editor-in-Chief of this journal.

\section{Competing interests}

The authors declare that they have no competing interests.

\section{Publisher's Note}

Springer Nature remains neutral with regard to jurisdictional claims in published maps and institutional affiliations.

Received: 7 July 2017 Accepted: 20 November 2017

Published online: 17 December 2017

\section{References}

1. Koonings PP, Campbell K, Mishell Jr DR, Grimes DA. Relative frequency of primary ovarian neoplasms: a 10-year review. Obstet Gynecol. 1989;74:921-6.

2. Young JL, Cheng Wu X, Roffers SD, Howe HL, Correa C, Weinstein R. Ovarian cancer in children and young adults in the United States, 1992-1997. Cancer. 2003;97(S10):2694-700.

3. Low JJH, Ilancheran A, Ng JS. Malignant ovarian germ-cell tumours. Best Pract Res Clin Obstet Gynaecol. 2012;26(3):347-55.

4. Park J-Y, Kim D-Y, Suh D-S, Kim J-H, Kim Y-M, Kim Y-T, et al. Analysis of outcomes and prognostic factors after fertility-sparing surgery in malignant ovarian germ cell tumors. Gynecol Oncol. 2017;145(3):513-8.

5. Brewer M, Gershenson DM, Herzog CE, Mitchell MF, Silva EG, Wharton JT. Outcome and reproductive function after chemotherapy for ovarian dysgerminoma. J Clin Oncol. 1999;17(9):2670.
6. Pautier $P$, Lhommé $C$. Traitement des tumeurs germinales de l'ovaire. In: Guastalla J, Ray-Coquard I, editors. Les Cancers Ovariens. Paris: Springer; 2006. p. 485-97.

7. Perrin LC, Low J, Nicklin JL, Ward BG, Crandon AJ. Fertility and ovarian function after conservative surgery for germ cell tumours of the ovary. Aust N Z J Obstet Gynaecol. 1999;39(2):243-5.

8. Low JJ, Perrin LC, Crandon AJ, Hacker NF. Conservative surgery to preserve ovarian function in patients with malignant ovarian germ cell tumors. Cancer. 2000;89(2):391-8.

9. Yang Z, Liu Z, Wei R, Li L. An analysis of prognostic factors in patients with ovarian malignant germ cell tumors who are treated with fertility-preserving surgery. Gynecol Obstet Invest. 2015;81(1):1-9.

10. Ertas IE, Taskin S, Goklu R, Bilgin M, Goc G, Yildirim Y, et al. Long-term oncological and reproductive outcomes of fertility-sparing cytoreductive surgery in females aged 25 years and younger with malignant ovarian germ cell tumors. J Obstet Gynaecol Res. 2014;40(3):797-805.

11. Sagae S, Sasaki H, Nishioka Y, Terasawa K, Kudo R. Reproductive function after treatment of malignant germ cell ovarian tumors. Mol Cell Endocrinol. 2003;202(1-2):117-21.

12. Tangir J, Zelterman D, Ma W, Schwartz PE. Reproductive function after conservative surgery and chemotherapy for malignant germ cell tumors of the ovary. Obstet Gynecol. 2003;101(2):251-7.

13. Solheim $O$, Tropé CG, Rokkones E, Kærn J, Paulsen T, Salvesen HB, et al. Fertility and gonadal function after adjuvant therapy in women diagnosed with a malignant ovarian germ cell tumor (MOGCT) during the "cisplatin era". Gynecol Oncol. 2015;136(2):224-9.
Submit your next manuscript to BioMed Central and we will help you at every step:

- We accept pre-submission inquiries

- Our selector tool helps you to find the most relevant journal

- We provide round the clock customer support

- Convenient online submission

- Thorough peer review

- Inclusion in PubMed and all major indexing services

- Maximum visibility for your research

Submit your manuscript at www.biomedcentral.com/submit
C Biomed Central 